Egyptian Journal of Aquatic Biology \& Fisheries

Zoology Department, Faculty of Science,

Ain Shams University, Cairo, Egypt.

ISSN $1110-6131$

Vol. 25(6): 145 - 164 (2021)

www.ejabf.journals.ekb.eg

\title{
Provisional Checklists on Blackwater Fish from the Peat Swamp in Terengganu, West Coast of Peninsular Malaysia.
}

\author{
Hussin-Jasmin N. ${ }^{1}$, Azmir I. $\mathrm{A}^{2,3^{*}}$ and Esa Y. B. ${ }^{4}$
}

${ }^{1}$ Faculty of Applied Sciences, Universiti Teknologi MARA (UiTM) Shah Alam, Selangor, Malaysia.

${ }^{2}$ School of Biology, Faculty of Applied Sciences, Universiti Teknologi MARA (UiTM) Negeri

Sembilan, Kampus Kuala Pilah, Pekan Parit Tinggi, Negeri Sembilan, Malaysia.

${ }^{3}$ EMiBio Special Interest Group, Faculty of Applied Sciences, Universiti Teknologi MARA

(UiTM) Negeri Sembilan, Kampus Kuala Pilah, Pekan Parit Tinggi, Negeri Sembilan, Malaysia

${ }^{4}$ Department of Aquaculture, Faculty of Agriculture, Universiti Putra Malaysia, Malaysia.

*Corresponding Author: izzati_adilah@uitm.edu.my

\section{ARTICLE INFO}

Article History:

Received: June 8, 2021

Accepted: July 28, 2021

Online: Dec. 13, 2021

Keywords:

Peat swamp fish,

Species richness,

Kemaman Terengganu,

Peninsular Malaysia,

Logging.

\section{ABSTRACT}

The blackwater fish species endemic to the peat swamp is economically and ecologically important in Southeast Asia, notably Malaysia. This report is the first peat swamp fish species of Kampung Yak Yah, Kemaman, Terengganu, (KYYKT), west coast of Peninsular Malaysia, aimed to document the fish species richness and update the provisional fish checklist in Malaysia. All species were collected from several stagnant blackwater peat swamps. A total of 14 species of freshwater fish from six families were recorded, and the most dominant family recorded was Cyprinidae $(n=7)$, followed by Osphronaemidae, comprised of four species. Meanwhile, other families of Anabantidae, Siluridae, and Zenarchopteridae contributed at least one species each. Hence, more species may be recorded in future studies applying other sampling methods, such as the electrofishing technique, and believably be able to add a few more fish species to the checklist.

\section{INTRODUCTION}

To date, approximately 114 peat swamp fish species from 23 families have been recorded in Malaysia, which included 49 species belonging to 18 families, 13 species from seven families, 58 species belonging to 19 families, and nine species from five families distributed throughout the peat swamps of Perak, Johor, Pahang, and East Peninsular Malaysia (parts of Pahang and Terengganu respectively), (Sule et al., 2016). Owing to the advancement in genetic studies, the quantity of the species was expected to increase, particularly for cryptic species. However, claimed by many researchers that the ichthyological study in Malaysia is still less intact in the discovery and exploratory stage (Ahmad and Khairul-Adha, 2005; Chong et al., 2010; Khairul, 2011; Ng et al., 2019) and, until today, lack of centralized taxonomy conduct. In some cases, the pioneer of fish 
became invariable as living components of water bodies are incredibly crucial as food resources (Sampantamit $\boldsymbol{e t}$ al., 2020), high in economic value (aquarium trade) (Livengood and Chapman, 2011; Ng, 2016), and a good bioindicator (Plessl et al., 2017) towards the ecological health (Bagra et al., 2009; Canning and Death, 2018).

Freshwater organisms inhabit streams, and over kilometres spread scale of peat swamp in Terengganu, Malaysia; this area contains diverse species of flora and fauna (UNDP, 2006). Based on a previous study of the fish species composition in the selected peat swamp areas in Kuala Langat and Sungai Dusun Selangor, Malaysia, 22 fish species were recorded representing ten different fish families (Ahmad and Samat, 2015). The study also found the Desmopuntius hexazona, Anabas testudineus, Belontia hasselti, and Trichopodus trichopterus were among the common species that inhabit the high acidity blackwater peat swamps.

The Kampung Yak Yah Kemaman Terengganu (KYYKT) Peninsular Malaysia's peat swamps which are typically blackwater areas, are inhibited by stenotopic fish species (narrowly adapted to specific environmental factors such as high acidity of the water) (Fahmi-Ahmad et al., 2015). Different habitats have established diverse niche types in the swamp ecosystem (Ahmad and Samat, 2015) and reflect the hydrology, peat thickness, and nutrient availability (Rieley, 2016). They vary from a mixed peat swamp community with up to 240 tree species per hectare to a less diverse, sparsely covered canopy, minimal pole forest, and frequently related in peatland nutrient availability and hydrology probably exert strong influences on forest structure and composition (Page $\boldsymbol{e} t$ al., 1999). Thus, tall peat swamp forest sub-types, which have the highest tree species diversity and canopy stratification, support the greatest faunal compared to lower canopy sub-types which comprised fewer species diversity (Rieley, 2016).

Apparently, the fish species richness in the blackwater peat swamp of KYYKT has yet to be explored, and a large area of flora and fauna is available to flourish. However, this peat swamp forest has been surrounded by logging activities that potentially reduced certain habitats within this area, especially the remnants of the blackwater. Considering this situation, the uniqueness of the blackwater peat swamp seems not a long endured and actively threatened by anthropogenic activities (i.e., illegal logging, urbanisation, and agriculture) (Shuhada et al., 2017). In addition, Malaysia has become one of the countries with vast peat swamp forests that appear to perceive them as wastelands that need to be turned into more productive land use (Posa et al., 2011).

Moreover, simple taxonomy literature is currently scarce, and it was not easy to enumerate all species in Malaysia in a single exercise accurately. However, the introduction of MyBIS (Malaysia Biodiversity Information System) as an established website for identifying the ornamental fish species in peat swamp made it an excellent platform. Thus, in this study, the rapid assessment of ornamental fish in peat swamp of blackwater in KYYKT was carried out to document the fish species richness as reference data that may be useful for habitat management and conservation plans in the future. 


\section{MATERIALS AND METHODS}

\section{Samples Collection}

The sampling locations were listed in Table 1 . These sites were randomly selected on their accessibility by car. The geographic coordinates of each sampling site were tracked using a global positioning system (GPS) to mark their location. The sampling sessions were conducted during a monsoon season (between November to March), and fish were sampled in the blackwater peat swamp that aligned with the stream of Sungai Bungkus, Jalan Ibok, KYYKT (Figure 1) using the technique of handheld push net with a mesh size of $3 \mathrm{~mm}$ (Aqmal-Naser and Ahmad, 2021).

The peat swamp characteristics, including general water conditions such as temperature and $\mathrm{pH}$ of the chosen habitat, were recorded for all locations using high $\mathrm{pH}$ resolution with an accuracy of \pm 0.1 known as HI98107 tester (HI 98107; Hannah pHep®) that displayed both $\mathrm{pH}$ and temperature readings simultaneously. Some of these fish were caught at slow-moving drainage and stagnant blackwater with vegetation distributed below the water's surface during the sampling time. Observations were made whenever

Table 1: The parameters of sampling sites in the peat swamp of KYYKT, west coast of Peninsular Malaysia.

\begin{tabular}{cccc}
\hline $\begin{array}{c}\text { Stations/ } \\
\text { Locations }\end{array}$ & $\begin{array}{c}\text { Temperature } \\
\left({ }^{\circ} \mathbf{C}\right)\end{array}$ & $\mathbf{p H}$ & Coordinate of location \\
\hline S1 & 25.0 & 5.5 & $4.288503,103.350275$ \\
S2 & 25.3 & 5.5 & $4.288487,103.350231$ \\
S3 & 28.5 & 7.4 & $4.288556,103.350630$ \\
S4 & 27.0 & 7.6 & $4.288434,103.350510$ \\
S5 & 25.5 & 7.0 & $4.28853,103.34933$ \\
\hline
\end{tabular}

possible using the wide-angle double lens digital camera model of the iPhone 11 . These samples were then preserved in 95\% ethanol and brought to the laboratory for proper identification. For checklist reliability, the conservative approach prefers not to refer to any inventory report that adopted non-authoritative references for taxonomic identification or has listed species that are invalid or ambiguous (Ng et al., 2019). Therefore, the reference was referred from Malaysia Biodiversity Information System (MyBis) (https://www.mybis.gov.my/one/) and comprehensively reviewing published literature (Conway and Kottelat, 2011; Arbuswan et al., 2012; Kottelat et al., 2013; Ng and Kottelat, 2013; Lumbantobing, 2014; Behera et al., 2015; Aqmal-Naser and 
Ahmad, 2021). MyBis defined as a one-stop repository established following Article 18(3) to provide the information exchange platform on biological diversity in Malaysia. It was accomplished as central node for a global network of the websites with Conventional on Biological Diversity (CBD) website (www.cbd.int) and performed as national nodes of the network in which the information was abstracted from publication, journals, expert checklists, and specimen databases (Mamat et al., 2015).

\section{RESULTS AND DISCUSSION}

The peat swamp area in Terengganu holds several remaining stagnant blackwaters that have yet to be studied extensively, making this study vital in educating and informing the community about the existence of fish fauna in these areas. A total of 14 species from six families of freshwater fishes were recorded during the surveys from five stations of blackwater peat swamp in KYYKT. There were 12, 29, 17, 15, and 22 fish samples collected from stations 1,2,3,4, and 5, respectively (Table 2). The family Cyprinidae and Osphronaemidae made up a significant proportion of fish fauna in this peat swamp area. Both families were the most dominant freshwater fish that endemic to blackwater peat swamp in Peninsular Malaysia (Ismail et al., 2015; Sule et al., 2016). The blackwater peat swamp possessed characteristically low dissolved oxygen and buffering capacity associated with high acidity and tannin color (Beamish et al., 2003). This study found three fish species from the family Cyprinidae and Osphronaemidae were caught with one representative, namely Anabas testidineus, Luciocephalus pulscher, and Esomus metallicus. Some species included those in the families Anabantidae, Belontidae, Channidae, and all represented in the peat swamp area equipped with a superbranchial organ that facilitates oxygen uptake even in oxygen-deficient water (Beamish et al., 2003).

Based on the result in Table 2, the checklist and composition were recorded in the blackwater peat swamp revealed a lower number of species compared to a previous study reported by Ismail et al (2015) which approximately 41 species from 13 families were collected from blackwater peat swamp in North Selangor, Peninsular Malaysia. Apparently, minimal species number found through this sampling compared to actual species number of fish species living in the peat swamp was possibly due to i) deforestation was a source of habitat destruction and became a contributing factor towards depletion of fish species in the remnants of blackwater peat swamps (Posa $\boldsymbol{e t}$ al., 2011; Ahmad and Samat, 2015; Rieley, 2016; Lo et al., 2020); ii) sampling method influence the type and number of fish samples caught (Beamish et al., 2003; Port et al., 2006; Aqmal-Naser and Ahmad, 2021) and iii) water parameters could influence the fish occurrence (Irvine et al., 2013; Zhao et al., 2017; Sule et al., 2018; Rashid et al., 2018). 


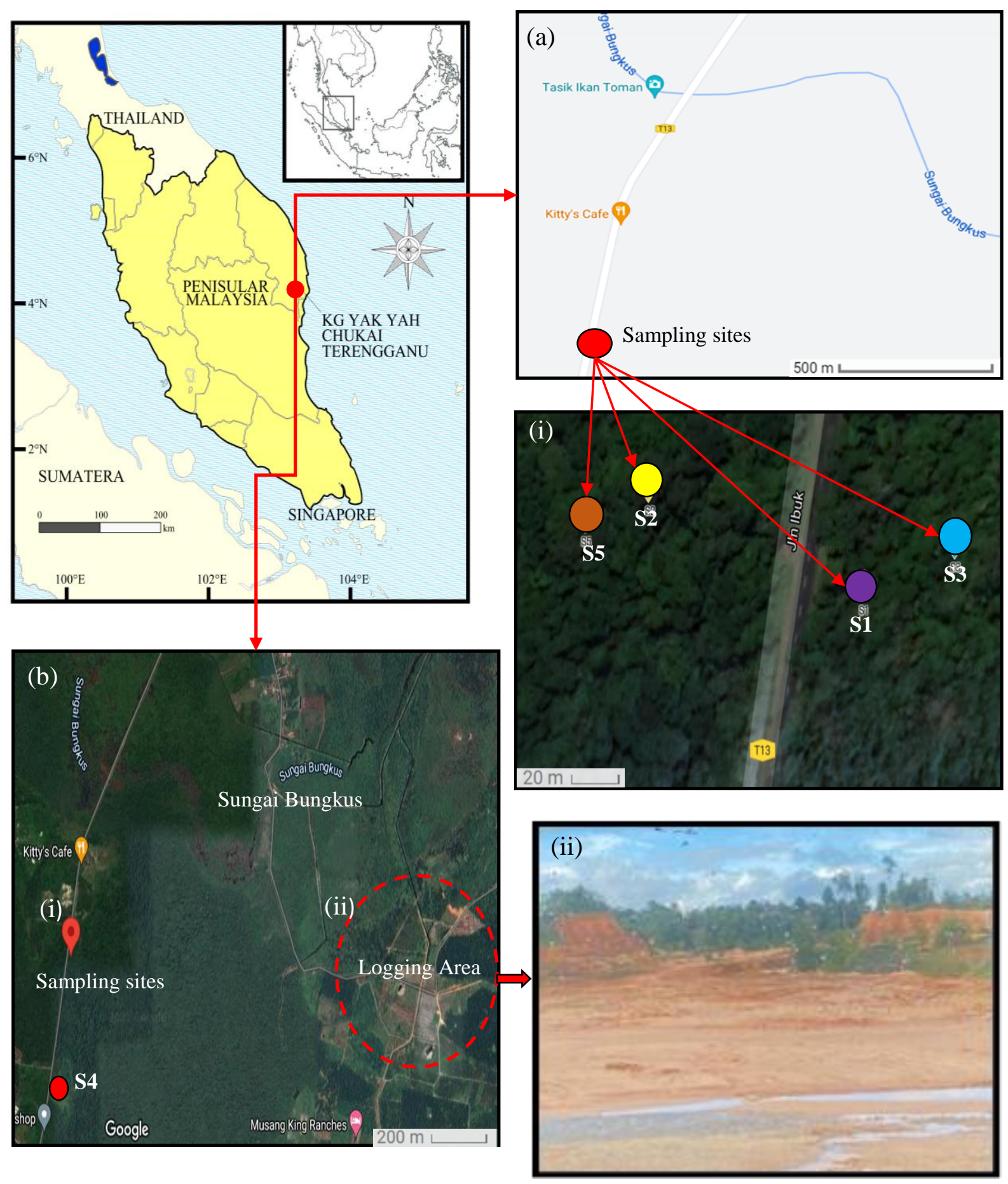

Figure 1 The Peninsular Malaysia map showed Kampung Yak Yah, Chukai, Terengganu highlighting the measured distance logging area estimated $2 \mathrm{~km}$ from the sampling sites (a) and (b) along Jalan Ibok, which connected to the river of Sungai Bungkus (i) Stations (S1-S5), (i) S1 and (ii) Logging area. 
Table 2. The provisional checklist and composition of fish fauna were recorded in each station of peat swamp of Kg Yak Yah, Kemaman, Terengganu.

\begin{tabular}{|c|c|c|c|c|c|c|}
\hline \multirow[t]{2}{*}{ Family/Species } & \multirow{2}{*}{$\begin{array}{l}\text { IUCN } \\
\text { Status }\end{array}$} & \multicolumn{5}{|c|}{ Stations } \\
\hline & & $\begin{array}{c}\text { S1 } \\
(n=12)\end{array}$ & $\begin{array}{c}\text { S2 } \\
(n=29)\end{array}$ & $\begin{array}{c}\text { S3 } \\
(n=17)\end{array}$ & $\begin{array}{c}\text { S4 } \\
(n=15)\end{array}$ & $\begin{array}{c}\text { S5 } \\
(\mathrm{n}=22)\end{array}$ \\
\hline \multicolumn{7}{|l|}{ Cyprinidae } \\
\hline Boraras maculatus & $\mathrm{LC}$ & - & - & - & - & + \\
\hline Desmopuntius hexazona & $\mathrm{LC}$ & + & + & + & - & - \\
\hline Esomus metallicus & $\mathrm{LC}$ & + & - & - & - & - \\
\hline Rasbora borapatensis & $\mathrm{LC}$ & + & - & - & + & + \\
\hline Rasbora einthovenii & $\mathrm{LC}$ & + & + & + & + & + \\
\hline $\begin{array}{l}\text { Trigonopoma } \\
\text { pauciperforatum }\end{array}$ & $\mathrm{LC}$ & + & + & + & + & - \\
\hline \multicolumn{7}{|l|}{ Cobitidae } \\
\hline Kottelatlimia pristes & VU & + & + & + & - & + \\
\hline \multicolumn{7}{|l|}{ Osphronaemidae } \\
\hline Belontia hasselti & $\mathrm{LC}$ & - & + & + & + & - \\
\hline Luciocephalus pulcher & $\mathrm{LC}$ & + & - & - & - & - \\
\hline Trichopodus trichopterus & $\mathrm{LC}$ & + & + & - & + & + \\
\hline Trichopsis vittata & $\mathrm{LC}$ & + & + & + & + & + \\
\hline \multicolumn{7}{|l|}{ Anabantidae } \\
\hline Anabas testidineus & DD & + & - & - & - & - \\
\hline \multicolumn{7}{|l|}{ Siluridae } \\
\hline $\begin{array}{l}\text { Kryptopterus } \\
\text { macrocephalus }\end{array}$ & NT & + & + & + & - & - \\
\hline \multicolumn{7}{|l|}{ Zenarchopteridae } \\
\hline $\begin{array}{l}\text { Hemirhamphodon } \\
\text { pogonognathus }\end{array}$ & $\mathrm{LC}$ & + & + & + & - & + \\
\hline
\end{tabular}

Note: += present; - =absent; $\mathrm{n}=$ number of samples; $\mathrm{LC}=$ Least Concern; $\mathrm{DD}=$ Data Deficient; $\mathrm{NT}=$ Near Threatened; VU= Vulnerable.

The stipulated data revealed that the most blackwater peat swamp area's highest richness was $\mathrm{S} 1$, and the lowest represented by S4 (Table 2). Station 1 was a waterlogged and nutrient-poor habitat. However, it hosts a distinctly adapted, highly endemic fish fauna, the glass Malayan fish (Kryptopterus macrocephalus), which is a near-threatened (NT) fish species (Ng and Kottelat, 2013). The characteristics of S1 showed the feature of a typical undisturbed area irrigated by blackwater with a highly acidic $\mathrm{pH}$ reading of 5.5 and a widely distributed swamp area estimated $2 \mathrm{~m}$ to $4 \mathrm{~m}$ wide, in-depth ranging from 0.5 to $2 \mathrm{~m}$ deep. The substrate was peat with submerged logs, and at some parts, gravels with leaves and branches from the trees covering the bottom surface. Thus, a higher number of species was found in this type of habitat in the studied area. In contrast, the peat swamp with higher sunlight exposure was only favored by a few types of species, including Trichopodus pectoralis, Hemibagrus nemurus, Rasbora dusonensis (Sule et al., 2018). The form of substrates in S4 was 
peat with fewer submerged logs and fewer leaves and branches at the bottom surface compared to S1.

On the other hand, $\mathrm{S} 4$ possessed a higher $\mathrm{pH}$ (7.6) comprised width of $2 \mathrm{~m}$ to $4 \mathrm{~m}$; in-depth ranging from $3 \mathrm{~m}-4 \mathrm{~m}$ deep and showed the least recorded number of species which revealed only six species compared to $\mathrm{S} 1$ (12 species) and the remaining stations S2 (nine species); S3 (eight species) and S5 (seven species). Based on Ahmad and Samat (2015), the most favorable habitat by the fish in peat swamps was significantly shadier and densely occupied with submerged aquatic plants such that habitat conditions had provided suitable niches for fish species like Rasbora kalochroma and Betta hipposideros. A similar result perceived by Wright and Flecker (2004) revealed that the woody ecosystem produced diverse fish compared to non-woody and comprised a greater number of cryptic species. This is because the woods in the peat swamp act as a refuge and provide food for the fishes that could help to increase their survivorship (Ahmad and Samat, 2015).

The peat swamp forest had been actively impacted by anthropogenic activities such as destruction through drainage and conversion to agricultural land (Irvine $\boldsymbol{e t}$ al., 2013). The data from forestry assessment revealed that selective logging caused alterations in forest composition and structure (Posa et al., 2011). For instance, canals used for floating logs are usually used for illegal logging as they disrupted the hydrological condition and caused the peat swamp forests more vulnerable to fire (Posa et al., 2011). The repercussion of fires in 1997-1998 previously had degraded forest by logging and drainage, revealed strong evidence in the form of extremely destroyed as well as uncontrollable areas in the land-cover distribution of Southeast Asia's peatlands (Miettinen et al., 2012).

The water temperature and $\mathrm{pH}$ in $\mathrm{S} 1\left(24^{\circ} \mathrm{C} ; \mathrm{pH} 5.5\right)$ were recorded lower than $\mathrm{S} 4$ $\left(27^{\circ} \mathrm{C} ; \mathrm{pH} 7.6\right)$ and most likely influenced the number of fish species diversity in the blackwater peat swamp. According to Sule et al. (2018), water temperature also exhibited significant parameters to control fish occurrence in a peat swamp and various ecosystem habitats. The result well agreed with Rashid et al. (2018) water conditions relative to basic requirements of biotic species especially fish frequently employed because various parameters of water quality criteria have been shown high probably to influence fish populations in a broad range of aquatic ecosystems. Due to the climatic condition, some of water parameters such as the $\mathrm{pH}$ values were recorded higher in the wet season caused by rainfall occurred during the sampling (Zakeyuddin et al., 2014). Hence, the distribution and abundance of some fish species are known to change over time scales, and these changes significantly affect survey results (Zhao et al., 2016). For example, a study conducted in a mountain stream of north Tiaoxi River, China, found the water $\mathrm{pH}$ had significant interactions with fish assemblages ( $\mathbf{L i}$ et $\boldsymbol{a l}$, 2012) whereas the water temperature and transparency in the wetland of Cross River, Nigeria clarified the spatial and seasonal changes in fish abundance (Rashid et al., 2018).

The family composition recorded between this study and other studies (Beamish et al., 2003; Ismail et al., 2015) was slightly different since the variety of sampling methods' practiced could contribute to biasness when compared directly. The number of fish species obtained during a survey is directly influenced by the sampling 
technique applied; for instance, the electrofishing technique applied by Beamish $\boldsymbol{e t}$ al. (2003) proved a total of 35 fish species were collected in the blackwater of North Selangor peat swamp. The efficiency of different sampling gears required knowledge of the fish populations and communities as well as their habitats (Portt et al., 2006). More fish species will be collected with the continuous collection of fish species associated with efficient sampling techniques, especially when using electrofishing to collect the underlying and cryptic species (Aqmal-Naser and Ahmad, 2021). Thus, deforestation, sampling technique, and contradictory results in water quality indicating that there could be a specific factor(s) that the provisional checklist in the peat swamp of KYYKT recorded a lower number of species.

\section{Fish Checklist from Peat Swamp in KYYKT, West Coast of Peninsular Malaysia Order Cypriniformes \\ Family Cyprinidae}

Boraras maculatus (Dunker, 1904) (Figure 2)

Remarks: The common name for this species is dwarf rasbora, and the color pattern varies depending on the population. The species possessed a large eye and head, rounded snout with smallmouth with the red and black pigment presence along the anterior edge of the dorsal and fins of males but not transparent (without red or black pigmentation in both sexes), which similar result to the sample that has been identified by Conway and Kottelat (2011) as Boraras naevus. This small-tomoderate size genus dwells throughout a wide area of Asia, including South China, Southeast Asia and the Indian Subcontinents (Lumbantobing, 2014). This species inhabits swamps and slow-flowing streams distributed throughout Peninsular Malaysia, Southern Thailand (Conway and Kottelat, 2011), and Eastern Sumatra (Wibowo et al., 2015).

\section{Desmopuntius hexazona (Weber and De Beaufort, 1912) (Figure 3)}

Remarks: D. hexazona is widely distributed and native to Southern Borneo, Eastern Sumatra, Singapore, and the Peninsular Malaysia. This species was found in North Selangor Peat Swamp Forest (NSPSF) (Ismail et al., 2015) that naturally an acidic ecosystem with pH ranging from 4.5 to 6.5 (Ahmad and Samat, 2015). This small, attractively patterned fish has been traded in the international market as ornamental fish; however still relies on catches from the wild (Fahmi et al., 2016). This species, previously known as Barbus hexazona (Kottelat et al., 2013), remains solved. It can be identified by the six equally spaced vertical dark bands, and the foremost band passed into the eye, and the rear band can be vaguely discerned at the bases of the tail fin. The third band abuts the front of the dorsal fin, and the maximum length can be reached until $5.5 \mathrm{~cm}$ (Parenti and Lim, 2005).

\section{Esomus metallicus (Ahl, 1923) (Figure 4)}

Remarks: This genus, known as flying barb, is widely distributed from the Indian sub-continent to Indochina, including Myanmar and the Peninsular Malaysia, and presently, 11 species were recognised as valid. The first record of this species was found in the small stream at Krmpal Village, Sumatra, Indonesia (Arbuswan et al., 2012). An elongated and compressed body can identify the cyprinid fish genus 
Esomus with a rounded abdomen comprised of a pair of maxillary barbels that are very long and reached the ventral fin origin. E. metallicus can be distinguished from its congeners by rostral barbels, which are not reaching beyond the posterior margin of the orbit, a black lateral band running from eye to caudal-fin base, and an incomplete lateral line with 10-18 perforated scales (Arbuswan et al., 2012).

\section{Rasbora borapetensis (Smith 1934) (Figure 5)}

Remarks: The Rasbora genus is the most species-rich in the cyprinid Danioninae subfamily (Lumbantobing, 2014). Recently, there 150 Rasbora species had been discovered (Aminan et al., 2020), which occurred in the great Mekong and Chao Phraya River drainages enormously been recorded from Cambodia, Laos, Vietnam, Peninsular Malaysia, and China. In Peninsular Malaysia, this species is widely distributed, particularly in North Selangor Peat Swamp Forest (Ahmad and Samat, 2015). Previously reported by Kottelat (1999), $R$. rubrodorsalis is closely related with its congener that emerged sympatrically with $R$. borapetensis over some of its geographical distribution and occasionally available for the aquarium trade. However, both can be easily differentiated from one another through external appearance such that dorsal fin $R$. borapetensis comprised colourless and can be found red pigmentation on the base of the caudal fin while $R$ rubrodorsalis possessed a bright red blotch in the dorsal fin. In addition, $R$. borapatensis served incomplete lateral lines with 10-15 perforated scales and non-existent black pigmentations in the fins (Rainboth, 1996).

\section{Rasbora eithovenii (Bleeker, 1851) (Figure 6)}

Remarks: This species is known as blue stripe rasbora or brilliant rasbora. According to its external morphology, it exhibits variable in its range by locality and has certain variations with a more indifferent or opaque lateral side stripe (Liao et al., 2010). The Rasbora genus was recorded in the Eastern Sumatran peat swamp that considered as the most threatened (Wibowo et al., 2015), and native to southern Thailand, Peninsular Malaysia, and the Greater Sunda Islands of Borneo and Sumatra which in Malaysia this species has been recorded in Johore and Sabah (www.mybis.gov.my).

\section{Trigonopoma pauciperforatum (Weber and De Beaufort, 1916) (Figure 7)}

Remarks: The $T$. pauciperforatum is one of the popular ornamental aquarium fish that possessed distinctive believe striking red neon stripe which aligned in parallel to its spine, starting from the side of the jaw, crossing the upper part of the eye and up till before its tail fin (Weber and De Beaufort, 1916). Owing to their high morphological similarity, these species are commonly misidentified with the glowlight Tetra (Hemigrammus erythrozonus) (Hung et al., 2020). This red striped rasbora fish is widely distributed in Southeast Asia, including Peninsular Malaysia, Sarawak, and Sumatra, which forming a school in stagnant blackwater (Ward 2003). The type of locality of this species is Sumatra, which is extensively developed, and overhanging vegetation is associated with minimal sun exposure with a slightly acidic tannin-stained swamp (Hung et al., 2020). 


\section{Family Cobitidae}

\section{Kottelatlimia pristes (Roberts, 1989) (Figure 8)}

Remarks: This species is synonym with Lepidocephalichthys pristes and has occasionally been exported for the aquarium trade. Formerly, Kottelat and Kelvin (1993) reported this species initially described as Kottelatlimia katik, which later found various aspects of this species, including scaleless head, small eyes, and comprised of nasal barbels. The attractive traits of this species were revealed when it could be distinguished from the others via the appearance of a dark spot at the anal-fin origin and two rows of spots on the anal-fin rays (Kottelat and Tan, 2008). This species can be found abundantly in Sumatra, Borneo and Peninsular Malaysia, which populate the acidic waters in swamp forests and tannin-stained blackwaters. Previously, this genus was reported to inhabit Sundalan peat swamp streams, Southeast Asia.

\section{Order Perciformes}

\section{Family Osphronaemidae}

\section{Belontia hasselti (Cuvier, 1831) (Figure 9)}

Remarks: This species synonyms with named Java combtail and Malay combtail, which native to Southern Indochina, from Southern (Peninsular) Thailand, throughout Peninsular Malaysia, Singapore, and the Greater Sunda Island Sumatra and previously this genus has been found in blackwater peat swamp of NSPSF, Selangor (FahmiAhmad et al., 2015). There were reported in Fishbase (www.fishbase.org) two species, Belontia hasselti (Malay Combtail and Belontia signata (Ceylonese Combtail). In addition, $B$. hasselti can be differentiate from their congeners by the presence of a mosaic-type pattern and appeared a dark sport on the posterior caudal fin based on the external characters (Kottelat, 2013).

\section{Luciocephalus pulcher (Gray, 1830) (Figure 10)}

Remarks: These species were known as the airbreathing fish due to a unique breathing apparatus (labyrinth organ) that inhabit streams of Borneo, Banka (Indonesia), Billiton, and Peninsular Malaysia (Liem, 1967). L. pulcher has been described from Endau drainage included regions of Pahang and Terengganu (Ng and Tan, 1999), one of the blackwater peat swamp in Peninsular Malaysia (Sule et al., 2016). The specialised organ was a maze-like structure associated with high vascularised folded flaps of the skin by modifying the first-gill arch. These species are easier to recognise by peppering the iridescent spots along their flanks easier to identify this species. It captured its prey by making a rapid plunge and surround the target with an open mouth (Ahmad et al., 2015).

\section{Trichopodus trichopterus (Pallas, 1770) (Figure 11)}

Remarks: This species, or the most common name, is three spot gourami or sepat, becoming popular ornamental fish native to Southeast Asia, widely distributed in Mekong Basin, Thailand, Cambodia, Vietnam, and Malaysia. The previous study claimed by Sule et al. (2018) this species was found endemic to the blackwater peat swamp of Selangor (NSPSF). The external background color revealed a light grey and may even be pale brown and two dark spots, which vary in size presently in the 
caudal peduncle and one in the middle of the body. This species can thrive in a complex range of environmental conditions and act as a biological indicator (Eviota et al., 2016).

\section{Trichopsis vittate (Cuvier and Valenciennes, 1831) (Figure 12)}

Remarks: These species are known as 'crocking gourami,' commonly found in weedy blackwater peat swamps distributed in many parts of Southeast Asia (Ahmad et al., 2015), including Peninsular Malaysia. The previous study has recorded this species distributed in blackwater peat swamp of Endau drainage ( $\mathbf{N g}$ and Tan, 1999), NSPSF, Selangor (Sule et al., 2016), and Eastern Sumatran, Indonesia (Wibowo et al., 2015). It resembled the 'fighting fish' of the genus Betta closely. According to Rainboth (1996), this genus can be diagnosed as the pelvic fin comprised a single spinous ray with filamentous extension and four branched rays whereby 2-4 spinous dorsal-fin rays and 4-8 spinous anal fin rays meanwhile, the lateral line was absent.

\section{Order Anabantiformes}

Family Anabantidae

\section{Anabas testidineus (Bloch, 1792) (Figure 13)}

Remarks: The climbing perch, Anabas testidineus is one of the most common freshwater fish species native in tropical and subtropical Asia and a carnivorous airbreathing species using a labyrinth organ (Morioko et al., 2009). This species is widely distributed, including India, Southern China, the Philippines, and Indonesia (Tan and Lim, 2004). This species has been reportedly found in the blackwater canal of North Selangor Peat Swamp Forest (NSPSF), located near Tanjung Karang, Selangor, Malaysia (Siow et al., 2013). This genus recorded two species, namely Anabas testidineus and Anabas oligolepsis, varying in size to differentiate such that $A$. testidineus is bigger in size than A. oligolepsis (Behera et al., 2015).

\section{Order Siluriformes}

\section{Family Siluridae}

\section{Kryptopterus macrocephalus (Bleeker, 1858) (Figure 14)}

Remarks: The transparent species, also called glass catfish, which are often found in ornamental fish trading, and among the most common members of the Siluridae ( $\mathbf{N g}$ and Kottelat, 2013). This unique species comprised a light brown body with prominent dark brown spots or stripes found only in Southeast Asia, including Malaysia. It was recorded from Sungai Kulak, Sarawak, which revealed the $\mathrm{pH}$ ranging from 3.74 to 3.90, and water was black in appearance. This species was widely distributed in Southeast Asia and seldom misidentified as Kryptoptericthys bicirrhis; however, the identification was clarified by $\mathbf{N g}$ and Kottelat (2013). The Kryptopterus macrocephalus was a commonly found species in the stagnant water and slow-moving blackwater peat swamp of Perak, Peninsular Malaysia (Ng et al., 2019). The IUCN declared this species under near-threatened (Ng, 2020). Thus, conservation is required to avoid this species from threatened status. 


\section{Order Beloniformes}

\section{Family Zenarchopteridae}

\section{Hemirhamphodon pogognathus (Bleeker, 1853) (Figure 15)}

Remarks: This species is widely distributed and can be found in Peninsular Malaysia, Singapore, Western Borneo, and Natuna (Aqmal-Naser and Ahmad, 2021). $H$. pogonathus has been found recorded in Nee Soon Swamp, Singapore, generally a shallow stream network, slow-flowing and acidic (with a mean $\mathrm{pH}$ of 5.2) (Ho et al., 2018). The family Zenarchopteridae comprised three genera, included Hemishamphodon, Dermogenys, and Nomorhampus. The Hemirhamphodon genus can be distinguished from its congeners which possessed pleural ribs beginning at the $2^{\text {nd }}$ vertebrate and anterior teeth extending around the jaw (Meisner, 2001). This species is fitted with a lower jaw that bends downwards longer than the upper jaw and occasionally the anterior tips. 


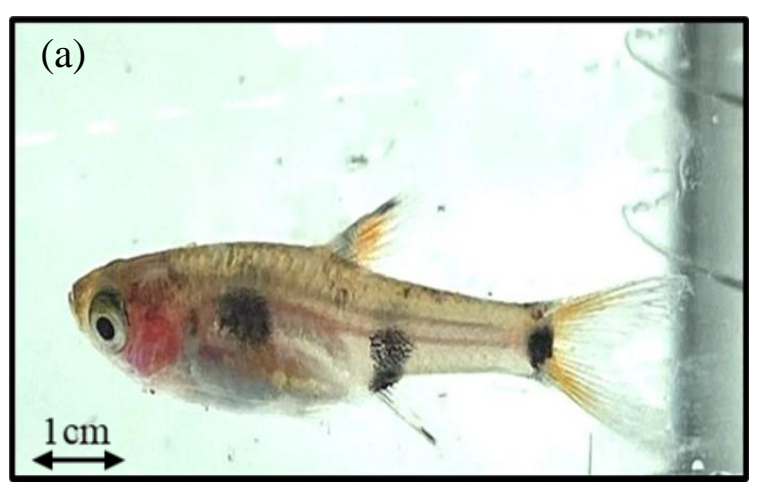

Figure 1 Boraras maculatus

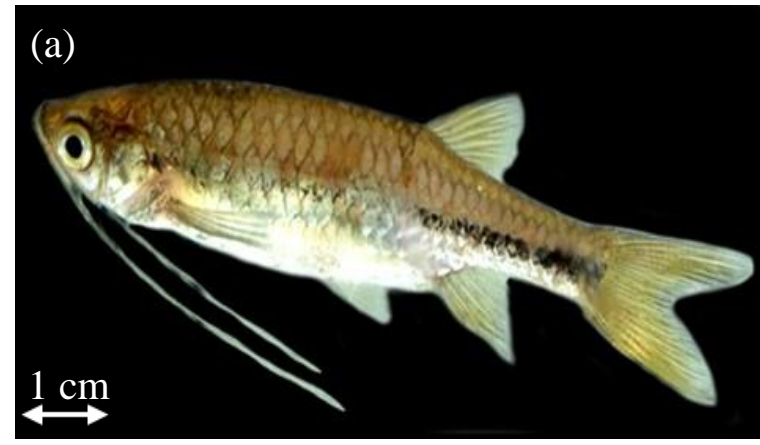

Figure 3 Esomus metallicus

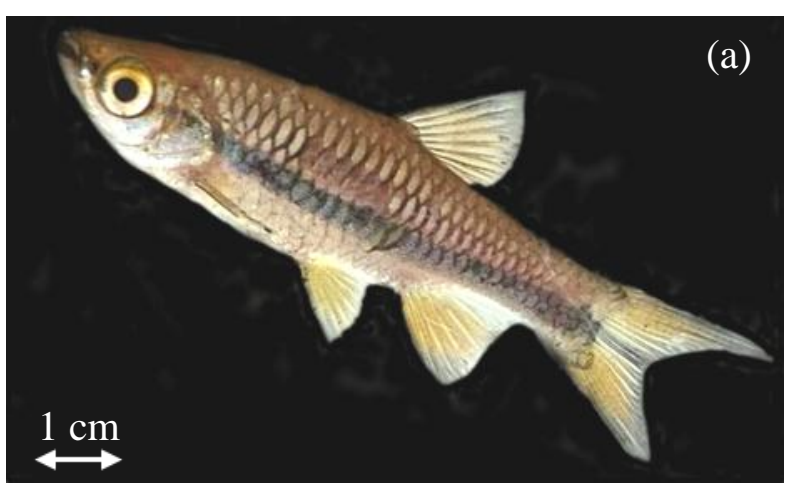

Figure 5 Rasbora einthovenii

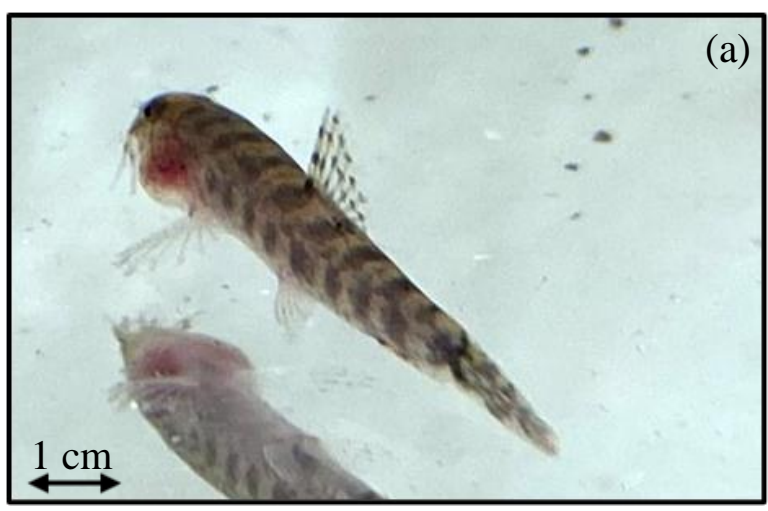

Figure 7 Kotteatlimia pristes

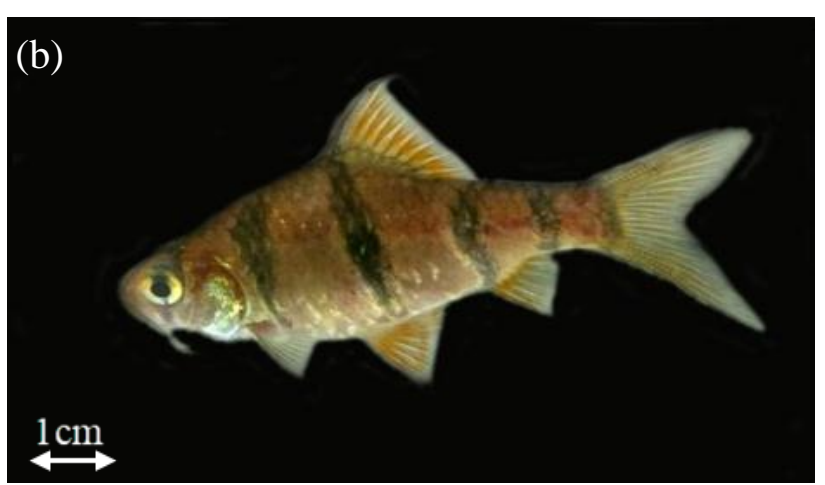

Figure 2 Desmopuntius hexazona

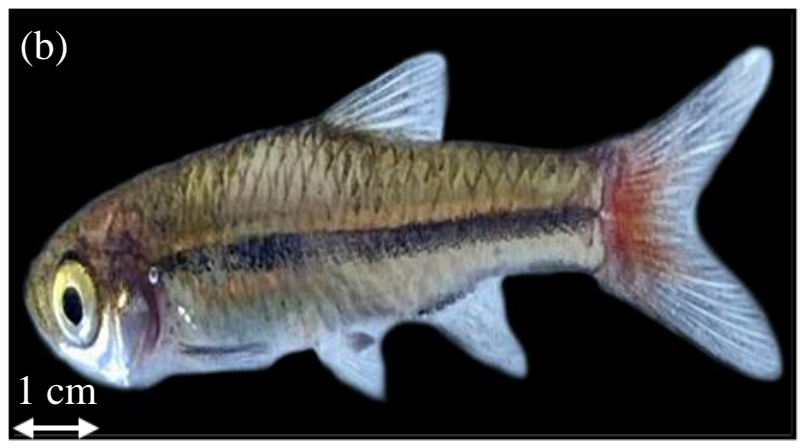

Figure 4 Rasbora borapetensis

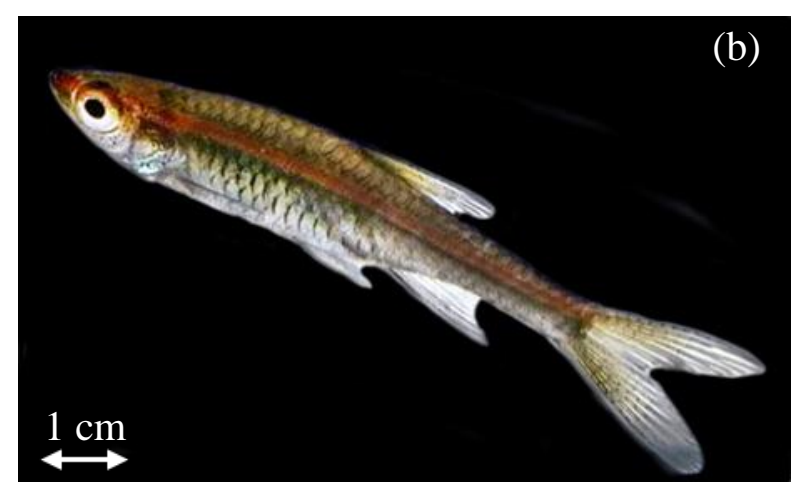

Figure 6 Trigonopoma pauciperforatum

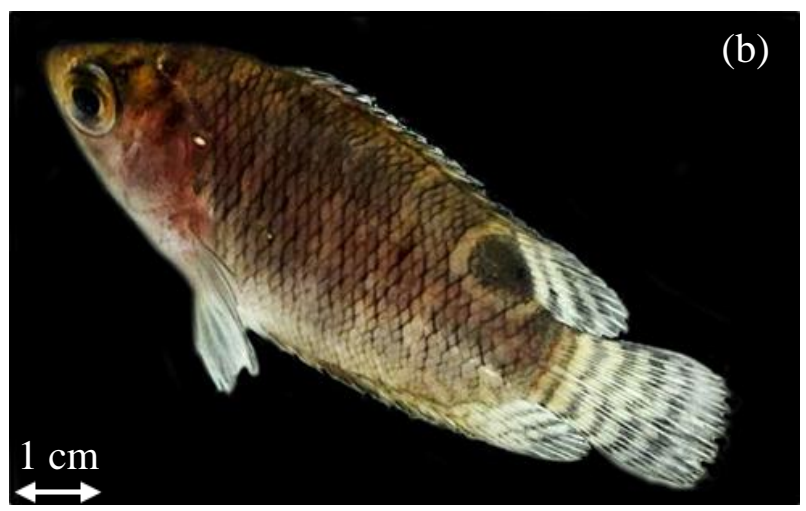

Figure 8 Belontia hasselti 


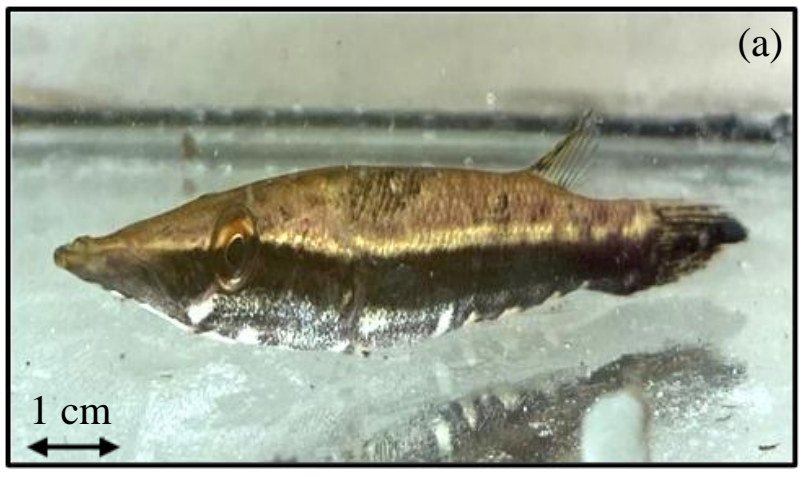

Figure 9 Luciocephalus pulcher

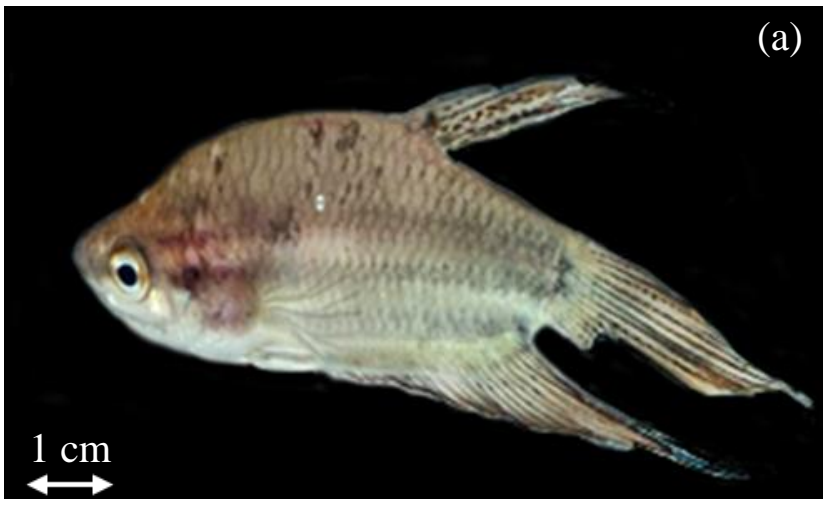

Figure 11 Trichopsis vittata

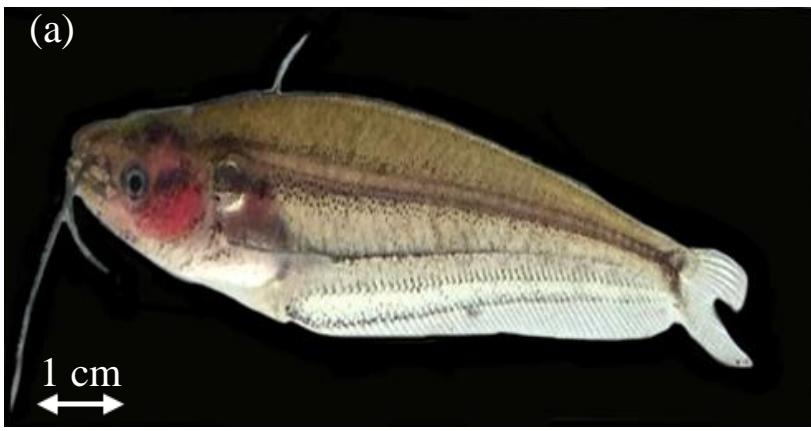

Figure 13 Kryptopterus macrocephalus

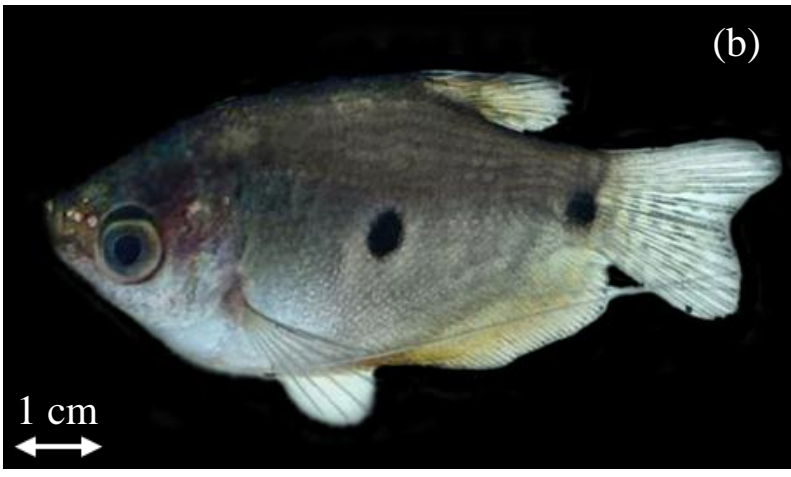

Figure 10 Trichopodus trichopterus

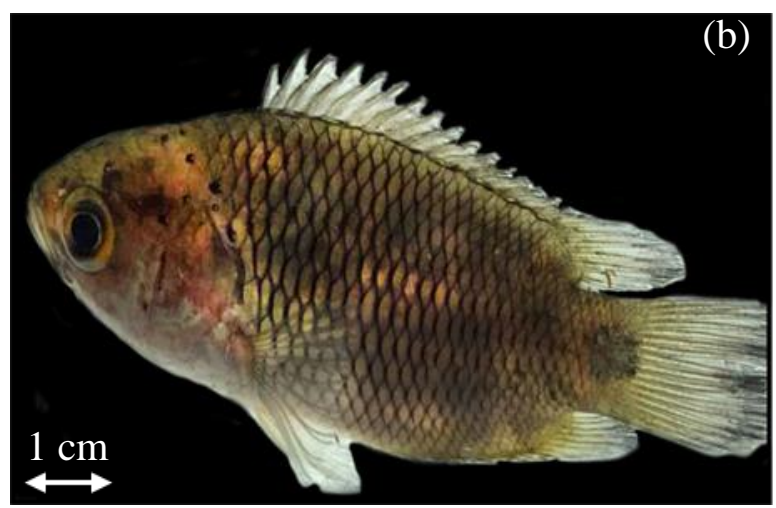

Figure 12 Anabas testidineus

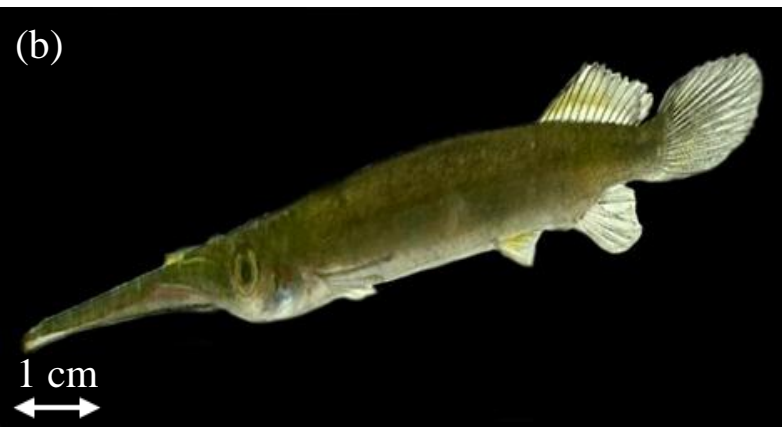

Figure 14 Hemirhamphodon pogonognathus 


\section{CONCLUSION}

The provisional checklist in the peat swamp of KYYKT was made to inform and educate the community as well as to spread awareness on the presence of unique species ornamental fish species in the area. Most of the species collected can be found in this habitat and possess an ornamental value; however, some species have become near threatened from the ongoing anthropogenic activities. Hence, proper management and conservation plans should be executed to ensure the preservation of natural habitat in KYYKT.

\section{ACKNOWLEDGEMENT}

We want to thank the Ministry of Higher Education, Malaysia under the Fundamental Research Grant Scheme (FRGS) (Ref. No: RACER/ 1/2019/ STG05/ UITM//5) through Universiti Teknologi Mara (UiTM) (Ref No: 600-IRMI/FRGSRACER 5/3 (058/2019) for fully funding this research. Not to forget, Universiti Teknologi Mara (UiTM) Cawangan Negeri Sembilan, Kampus Kuala Pilah for providing the facilities to conduct this study. Lastly, thank you to Nadhirah Ranizam and Sharifah NorBalqis for their assistance during the sampling session.

\section{REFERENCES}

Ahmad, A. and Khairul-Adha, A. R. (2005). State of Knowledge on Freshwater Fishes of Malaysia. Proceedings of the Seminar and Workshop. Forest Research Institute Malaysia, Kepong, Malaysia, 28-30 June

Ahmad, A.; Fahmi-Ahmad and Johari, M. N. (2015). Freshwater fishes of Jambu Bongkok Forest Reserve, Terengganu: Peninsular Malaysia. pp. 31-44.

Ahmad, M. F. and Samat, A. (2015). Species Composition and Abundance of Peat Swamp Fishes in Selected Areas of Selangor, Malaysia. Malaysian Applied Biology., 44:139-146.

Aminan, A. W.; Kit, L. L. W.; Hui, C. H. and Sulaiman, B. (2020). Morphometric Analysis and Genetic Relationship of Rasbora spp. in Sarawak, Malaysia. Trop. Life. Sci. Res., 31:33-49.

Aqmal-Naser and Ahmad, A. (2021). Preliminary Checklist of Freshwater Fishes of Ulu Paip Eco-Park Forest, Kedah, Peninsular Malaysia. Malaysian Journal of Applied Sciences., 50:1-14. 
Arbsuwan, S.; Musikasinthorn, P.; Marini, M. and Samhudi, H. (2012). First record of the cyprinid fish, Esomus metallicus (Actinopterygii: Cyprinidae) from Sumatra. Natural History Bulletin of the Siam Society., 58:59-65.

Bagra, K.; Kadu K.; Nebeshwar-Sharma, K.; Laskar, B.; Sarkar, U. and Das, D. N. (2009). Ichthyological Survey and Review of The Checklist of Fish Fauna of Arunachal Pradesh, India. Check List., 5:330-350.

Beamish, F. W. H.; Beamish, R. B. and Lim, S. L. H. (2003). Fish Assemblages and Habitat in a Malaysian Blackwater Peat Swamp. Environmental Biology of Fishes., 68:113.

Behera, S.; Laishram, M. D.; Sanjeev, K.; Gogoi, R.; Puspendu, S.; Olik, J. and Baksi, S. (2015). External Morphology and Sexual Dimorphism of Anabas Testudineus in Natural Environment. IJSN., 6: 288-292.

Canning, A. and Death, R. (2018). Ecosystem Health Indicators-Freshwater Environments. Encyclopedia of Ecology., 1:46-60

Chong, V. C. Lee, P. K. and Lau, C. M. (2010). Diversity, Extinction Risk, and Conservation of Malaysian Fishes. Journal Fish Biology., 76: 2009-2066.

Conway, K. and Kottelat, M. (2011). Boraras naevus, A New Species of Miniature and Sexually Dichromatic Cyprinid Fish from Peninsular Thailand (Ostariophysi: Cyprinidae). Zootaxa., 3002:45-51.

Eviota, MP.; Jumawan, J. C.; Joseph, C. C. D. and Samson, N. L. (2016). Geometric Morphometric Analysis of Three Spot Gourami, Trichopodus Trichopterus in Masao River, Butuan City, Mindanao, Philippines. AACL Bioflux., 9: 1011-1019.

Fahmi, M.; Musthofa, S.; Permana, A.; Zamroni, M. and Ginanjar, R. (2016). Perkembangan Larva Dan Ekologi Ikan "Six-Banded Tiger Barb" (Desmopuntius hexazona Weber and De Beaufort, 1912) di Cagar Biosphere Bukit Batu, Riau. Bawal Widya Riset Perikanan Tangkap. 8: 65-76.

Fahmi-Ahmad, M.; Rizal, S. A. and Ahmad, A. (2015). Ichthyofaunal Diversity of Tasek Bera Ramsar Site, Pahang, Peninsular Malaysia. Journal of Wildlife and Parks., 30:27-43.

Froese, R. and Pauly, D. (Editors) (2021). Fishbase Worldwide Web Electronic Publication. Retrieved from www.fishbase.org (Jun 28, 2021).

Ho, J.; Ramchunder, S.; Memory A.; Tan, H. and Yeo, D. (2018). Native and Introduced Fish Community Structure in A Freshwater Swamp Forest: Implications for 
Conservation and Management. Aquatic Conservation: Marine and Freshwater Ecosystems., 29:1-12

Hung, H. C.; Leonard, W. K. L.; Yunshi, L.; Tommy, T. Y. L. and Yee, L. C. (2020). Sequencing and Characterisation of Complete Mitochondrial DNA Genome for Trigonopoma pauciperforatum (Cypriniformes: Cyprinidae: Danioninae) with Phylogenetic Consideration. Tropical Life Sciences Research., 31: 107-121.

Irvine, K.; Vermette, S. and Firuza, M. (2013). The 'Black Waters' of Malaysia: Tracking Water Quality from the Peat Swamp Forest to the Sea. Sains Malaysiana. 42: 1539-1548.

Ismail, A.; Azmai M. N. A.; Talib, A.; Sepet, J.; Aziz, A. and Sule H. (2015). Fish Diversity of North Selangor Peat Swamp Forest, Selangor, Malaysia. Seminar Ekologi Malaysia. pp. 115-118.

Khairul-Adha, A. R. (2011). The Contribution of Non-indigenous Fish for Aquaculture Development in Malaysia. Majalah Akuakultur Malaysia, Ministry of Agriculture.

Kottelat, M. (1998). Fishes of The Nam Theun and Xe Bangfai Basins, Laos, with Diagnoses of Twenty-Two New Species (Teleostei: Cyprinidae, Balitoridae, Cobitidae, Coiidae and Odontobutidae). Ichthyol. Explor. Freshwat., 9: 1-128.

Kottelat, M. (2013). The Fishes of The Inland Waters of Southeast Asia: A Catalogue and Core Bibliography of The Fishes Known to Occur in Freshwaters, Mangroves, and Estuaries. The Raffles Bulletin of Zoology., Suppl. 27. 1-663.

Kottelat, M. and Kelvin, L. (1993). A Synopsis of the Malayan Species of Lepidocephalichthys, with Descriptions of Two New Species (Teleostei: Cobitidae). The Raffles Bulletin of Zoology., 40: 201-220.

Kottelat, M. and Tan, H. H. (2008). Kottelatlimia Hipporhynchos, A New Species of Loach from Southern Borneo (Teleostei: Cobitidae). Zootaxa., 1967:63-72.

Kottelat, M.; Britz, R.; Tan H. H. and Wilte K. E. (2006). Paedocypris, A New Genus of Southeast Asian Cyprinid Fish with A Remarkable Sexual Dimorphism, Comprises the World's Smallest Vertebrate. Proceedings of the Royal Society B., 273: 895-899.

Liao, T. Y.; Kullander S. O. and Fang, F. (2010). Phylogenetic Analysis of The Genus Rasbora (Teleostei: Cyprinidae). Zoologica Scripta., 39:155-176.

Liem, K. F. (1967). A Morphological Study of Luciocephalus Pulcher, with Notes on Gular Elements in Other Recent Teleosts. Journal of Morphology., 121: 103-133. 
Livengood, E. and Chapman, F. (2011). The Ornamental Fish Trade: An Introduction with Perspectives for Responsible Aquarium Fish Ownership ${ }^{1}$. Publication \#FA124. Fisheries and Aquatic Sciences (SFRC)., pp. 1-7.

Lumbantobing, D. N. (2014). Four New Species of Rasbora of The Sumatrana Group (Teleostei: Cyprinidae) from Northern Sumatra, Indonesia. Zootaxa. 3764: 1-25.

Mamat, H, Tan, K. K. and Ariffin, M. Y. (2015). Malaysia Biodiversity Information System (MyBIS). https://www.mybis.gov.my/art/15. (Feb 14, 2021).

Meisner, A. D. (2001). Phylogenetic Systematics of The Viviparous Halfbeak Genera Dermogenys and Nomorhamphus (Teleostei: Hemiramphidae: Zenarchopterinae). Zoological Journal of the Linnean Society., 133: 199-283.

Michael, D.; Ella A.; Tuen, A.; Chiron, I. and Kho, L. K. (2019). Fishes of a Conserved Peat Swamp Forest in an Oil Palm Plantation. Oil Palm Bulletin., 78:1-5

Miettinen, J.; Shi, C.; and Liew, S. C. (2012). Two Decades of Destruction in Southeast Asia's Peat Swamp Forests. Frontiers in Ecology and the Environment., 10: 124-128.

Morioka, S.; Ito, S.; Kitamura, S. et al. (2009). Growth and Morphological Development of Laboratory-Reared Larval and Juvenile Climbing Perch Anabas Testudineus. Ichthyol Research., 56: 162-171.

Ng, Casey. (2016). The Ornamental Freshwater Fish Trade in Malaysia. Utaragriculture Science Journal., 2: 7-18.

Ng, Casey.; Lim, T.; Ahmad, A. and Khaironizam, M. Z. (2019). Provisional Checklist of Freshwater Fish Diversity and Distribution in Perak, Malaysia, and Some Latest Taxonomic Concerns. Zootaxa., 4567:515-545.

Ng, H. H. and Kottelat, M. (2013). After Eighty Years of Misidentification, A Name for The Glass Catfish (Teleostei: Siluridae). Zootaxa., 3630:308-316.

Ng, H. H. and Tan, H. (1999). The Fishes of the Endau drainage, Peninsular Malaysia with Descriptions of Two New Species of Catfishes (Teleostei: Akysidae, Bagridae). Zoological Studies., 38:350-366.

Ng, H. H. (2020). Kryptopterus macrocephalus. The IUCN Red List of Threatened Species 2020: e.T181264A162835320. Retrieved from: https://dx.doi.org/10.2305/IUCN.UK.2020-2.RLTS.T181264A162835320.en. (April 4, 2021)

Parenti, L. and Lim, K. (2005). Fishes of the Rajang Basin, Sarawak, Malaysia. The Raffles Bulletin of Zoology., Supplement 13. 175-208. 
Plessl, C.; Otachi, E. O.; Körner, W.; Avenant-Oldewage, A. and Jirsa, F. (2017). Fish as Bioindicators for Trace Element Pollution from Two Contrasting Lakes in The Eastern Rift Valley, Kenya: Spatial and Temporal Aspects. Environmental Science and Pollution Research International., 24: 19767-19776.

Portt, C. B.; Ming, D. L.; and Randall, R. G. (2006). A Review of Fish Sampling Methods Commonly Used in Canadian Freshwater Habitats. Canadian Technical Report of Fisheries and Aquatic Sciences 2604., 1240: 1-51.

Posa, M.; Wijedasa L. and Corlett, R. (2011). Biodiversity and Conservation of Tropical Peat Swamp Forests. BioScience., 61: 49-57.

Rainboth, W. J. (1996). Fishes of the Cambodian Mekong. FAO Species Identification Field Guide for Fishery Purposes. F.A.O., Rome. p. 265.

Rashid, Z. A.; Amal, M. N. and Shohaimi, S. (2018). Water Quality Influences on Fish Occurrences in Sungai Pahang, Maran District, Pahang, Malaysia. Sains Malaysiana., 47:1941-1951.

Sampantamit, T.; Ho, L.; Lachat, C.; Sutummawong, N.; Sorgeloos, P. and Goethals, P. (2020). Aquaculture Production and Its Environmental Sustainability in Thailand: Challenges and Potential Solutions. Sustainability., 12: 1-17.

Shuhada, S. N.; Salim, S.; Nobilly, F. Zubaid, A. and Azhar, B. (2017). Logged Peat Swamp Forest Supports Greater Macrofungal Biodiversity Than Large-Scale Oil Palm Plantations and Smallholdings. Ecology and Evolution., 7: 1-14.

Siow, R.; Ramli, M. N.; Shakori, M. H. M. and Asmuni, M. (2013). Fish fauna Assemblages and Their Distribution Patterns in The North Selangor Peat Swamp Forest. Proceedings of the Seminar on Scientific Biodiversity Expedition, North Selangor Peat Swamp Forest, 28 November 2013, Quality Hotel, Shah Alam, Selangor, Malaysia. pp.77-82.

Sule H.; Ismail A.; and Azmai, M. N. A. (2016). A Review of The Ichthyofauna of Malaysian Peat Swamp Forest. Pertanika Journal of Tropical Agricultural Science., 39: 421-458.

Sule, H.; Ismail, A.; Zulkifli, S. Z.; Roseli, M. R. M. A. and Shohaimi, S. (2018). Water Quality Influences on Fish Occurrence in Peat Swamp Forest and Its Converted Areas in North Selangor, Malaysia. Sains Malaysiana., 47: 2589-2600.

UNDP. (2006). Malaysia's Peat Swamp Forests Conservation and Sustainable Use. Retrieve from www.undp.gov.my (Feb 6, 2020). 
Ward, B. (2003). The aquarium fish surviving manual (8th edition). Hauppauge, NY: Quill Publishing Limited.

Weber, M. and De Beaufort, L. F. (1916). The fishes of the Indo-Australian Archipelago. III. Ostariophysi: II Cyprinoidea, Apodes, Synbranchi. Leiden, Netherlands: E. J. Brill Ltd. p. 455.

Wibowo A.; Sloterdijk H. and Ulrich P. (2015). Identifying Sumatran Peat Swamp Fish Larvae through DNA Barcoding, Evidence of Complete Life History Pattern. Procedia Chemistry. 14:76-84.

Zakaria, R. (Exclusive). (2017). Experts worry over fate of world's 2nd smallest fish. Retrieved from https://www.nst.com.my/news/nation/2017/10/290287/exclusive-expertsworry-over-fate-worlds-2nd-smallest-fish. (Dec. 5, 2019).

Zakeyuddin, S.; Md, Sah.; Amir, SR.; Hashim, Z.; Khaled, P.; Syaiful, M.; Wan, O.; Wan, M. (2014). The Effect of Seasonal Changes on Freshwater Fish Assemblages and Environmental Factors in Bukit Merah Reservoir (Malaysia). Transylv. Rev. Syst. Ecol. Res., 16: 97-108.

Zhao, J.; Cao, J.; Tian, S.; Chen, Y.; Zhang, S. and Zhou, X. (2017). Influence of Sampling Frequency on Detectability of Fish Community and Fish Species in A FisheryIndependent Survey. Aquaculture and Fisheries., 2: 94-102. 